\title{
Conservation of estrogen receptor function in invertebrate reproduction
}

\author{
Brande L. Jones ${ }^{1 *}$, Chris Walker ${ }^{2}$, Bahareh Azizi ${ }^{3}$, Laren Tolbert ${ }^{2}$, Loren Dean Williams ${ }^{2}$ and Terry W. Snell ${ }^{1}$
}

\begin{abstract}
Background: Rotifers are microscopic aquatic invertebrates that reproduce both sexually and asexually. Though rotifers are phylogenetically distant from humans, and have specialized reproductive physiology, this work identifies a surprising conservation in the control of reproduction between humans and rotifers through the estrogen receptor. Until recently, steroid signaling has been observed in only a few invertebrate taxa and its role in regulating invertebrate reproduction has not been clearly demonstrated. Insights into the evolution of sex signaling pathways can be gained by clarifying how receptors function in invertebrate reproduction.

Results: In this paper, we show that a ligand-activated estrogen-like receptor in rotifers binds human estradiol and regulates reproductive output in females. In other invertebrates characterized thus far, ER ligand binding domains have occluded ligand-binding sites and the ERs are not ligand activated. We have used a suite of computational, biochemical and biological techniques to determine that the rotifer ER binding site is not occluded and can bind human estradiol.

Conclusions: Our results demonstrate that this mammalian hormone receptor plays a key role in reproduction of the ancient microinvertebrate Brachinous manjavacas. The presence and activity of the ER within the phylum Rotifera indicates that the ER structure and function is highly conserved throughout animal evolution.
\end{abstract}

Keywords: Rotifera, Receptor, Estrogen receptor

\section{Background}

Signaling through steroid receptors regulates development, growth and reproduction in most vertebrate animals [1-7]. Recently, concern has grown about susceptibility of aquatic invertebrates to endocrine disruption, which has been documented for vertebrates [8]. Endocrine disruption is the process by which certain chemicals, called endocrine disrupting compounds, interfere with the endocrine system and disrupt developmental, reproductive, neurological, and immune processes. Endocrine disrupting compounds are a subclass of organic contaminants that have been detected in wastewater and surface waters throughout the world [9].

Although steroid signaling is thought to be the chief means by which most animals regulate reproduction, it has been confirmed in only a few invertebrate taxa [10] and its regulatory role has not been generally

\footnotetext{
* Correspondence: brandejones@gatech.edu

${ }^{1}$ School of Biology, Georgia Institute of Technology, Atlanta, GA 30332-0230, USA

Full list of author information is available at the end of the article
}

demonstrated [7, 11-13]. Steroid signaling may be present in a much more diverse group of animals than currently demonstrated. Genome and proteome analysis indicates that modern steroid receptors evolved from an ancient receptor that arose more than $600 \mathrm{Ma}$ ago, before the common ancestor of bilaterians diverged into protostomes and deuterosomes [6].

Rotifera is one of the largest microinvertebrate phyla [14]. Although monogonont rotifers are capable of both asexual and sexual reproduction, the chemical signals regulating these are poorly understood. Sexual reproduction is triggered by a quorum sensing process [15], induced by secretion of a Mixis Inducing Protein (MIP) [16]. The similarity of MIP to a putative steroidogenesisinducing protein in humans [17] suggests that steroid hormones may have a role in regulating sexual reproduction in B. manjavacas.

The estrogen receptor (ER) is the most ancient of all of the sex steroid receptors $[2,4,5,18]$. However, there are disparities and inconsistencies in the known phylogenetic distribution of the ER in invertebrates and in the 
understanding of their function in sexual differentiation, development, reproduction and behavior. The supraphylum Lophotrochozoa is especially useful for studying the evolution of ER because some phyla such as annelids have ERs with the capacity to bind estradiol [7], while other phyla such as molluscs have ERs that do not bind estradiol [6]. Rotifera is a Lophotrochozoa phylum [19] that has yet to be explored for the presence of functional ERs.

Though steroid signaling has not been extensively studied in rotifers, there are several lines of evidence that support the hypothesis that steroid signaling may be an important mechanism of regulating rotifer reproduction. First, the steroidal hormone progesterone has been identified in rotifer biomass [13], and a progesterone receptor has been identified and characterized in the rotifer transcriptome [13, 20, 21]. Second, published rotifer transcriptomes [22, 23] contain several key enzymes required for sex steroid biosynthesis [24], including cytochrome $\mathrm{P} 4504 \mathrm{vC}$ (P450), estradiol 17-B dehydrogenase 12 (EST), sphingolipid delta 4 desaturase/c-4 hydroxylase (SPH), estrogen receptor binding protein (ERB), sterol O-acyltransferase 1 (SOA), and a steroid reductase (SR). Third, exposure to vertebrate steroids, including progesterone, causes an increase in rotifer sexual reproduction in vivo. [21, 25-29]. Moreover, rotifers are responsive to endocrine disrupting compounds $[28,30]$, implying that they use steroids to regulate their reproduction.

Unlike progesterone, neither estrogen nor testosterones have been detected in rotifer tissues [31]. Nonetheless, three genes have been identified in the rotifer transcriptome that are highly similar in sequence to genes known to promote both biosynthesis and activity of estradiol and estrogen receptors in other animals. These include a P450-like gene that has high similarity to aromatase. Aromatase is an enzyme that is responsible for a key step in biosynthesis of estrogens [32]. An estradiol 17-B dehydrogenase-like gene (EST) also was identified in the rotifer trancriptome as in other animals [33]. EST catalyzes the interconversion of testosterone, androstenedione, estradiol and estrone. Furthermore, an estrogen receptor binding protein (ERB) has been identified in the rotifer transcriptome. ERB enhances the activity of estrogen receptors [34]. The expression of these transcripts in B. manjavacas supports the hypothesis that steroid signaling plays a key role in rotifer reproduction and development.

The discovery of the progesterone receptor in rotifers $[13,20]$, as well as the previously described evidence of steroid signaling in rotifers, led us to investigate the possibility of expression of an estrogen receptor. We began by searching the transcriptome of $B$. manjavacas. Our search led to the identification of a sequence of 1148 nucleotides with $43 \%$ similarity to several animal ERs, including human, lamprey and several fish species. Identification of an estrogen-like receptor in the phylum Rotifera encouraged us to explore its role in endocrine signaling and reproductive physiology. We cloned and amplified the rotifer estrogen-like receptor ligand binding domain (LBD) and explored its binding partners. Here, we show that human estradiol binds to the rotifer estrogenlike receptor LBD and that human estradiol in vivo localizes to rotifer reproductive tissues. Using a library of newly synthesized fluorescent arylideneimidazolidinone (AMI) probes, our previous work showed selective binding of some probes to various sites on the human ER [35]. Here we show that many of these AMI probes also bind to the rotifer estrogen-like receptor, and selectively localize to specific tissues. The probes have no effect on rotifer survival, but in some cases enhance rotifer reproduction. This work shows that the rotifer estrogen-like receptor has a functional ligand binding site and is ligand-activated. Furthermore, this work provides evidence of the ancient origins of ligand-activated steroid receptors.

\section{Results}

\section{Identification and analysis of the B. manjavacas ER LBD}

The $B$. manjavacas estrogen-like receptor ligand binding domain (LBD) was identified by searching the $B$. manjavacas transcriptome for homology with the human ER LBD. The homologous rotifer sequence was used to design constructs for in vivo yeast assays. A CLUSTALW [36] alignment indicates there is $68 \%$ sequence similarity between human ER and rotifer estrogen-like receptor LBDs (Additional file 1: Figure S1 and Table 1). The human ER LBD, which has been crystallized, was used to construct a three-dimensional homology model of the rotifer ER LBD (Fig. 1). We developed an empirical error model, specific to ER LBDs, which allows us to estimate the uncertainty in the $B$. manjavacas estrogen-like LBD homology model.

\section{Confocal fluorescence}

AMI probes are ER LBD ligands that fluoresce upon binding [35], and allow probing of in vivo distributions of the rotifer estrogen-like receptor LBD. Fluorescence assays in which rotifers were treated with $A M I$ probes $A B-1, A B-9$, AB-18, AB-43, and AB-89, AB-114 (Additional file 2:

\begin{tabular}{llll}
\multicolumn{2}{l}{ Table 1 ER LBD sequences and structures are highly conserved } \\
\hline Species & $\begin{array}{l}\text { RMSD (structure vs. } \\
\text { model, A })\end{array}$ & $\begin{array}{l}\text { \% Sequence } \\
\text { identity vs. Human }\end{array}$ & $\begin{array}{l}\text { \% Sequence } \\
\text { similarity vs. human }\end{array}$ \\
\hline Human & 0 & 100 & 100 \\
Rat & .713 & 57 & 94 \\
Oyster & 1.45 & 33 & 72 \\
Rotifer & 1.69 & 25 & 68 \\
\hline
\end{tabular}




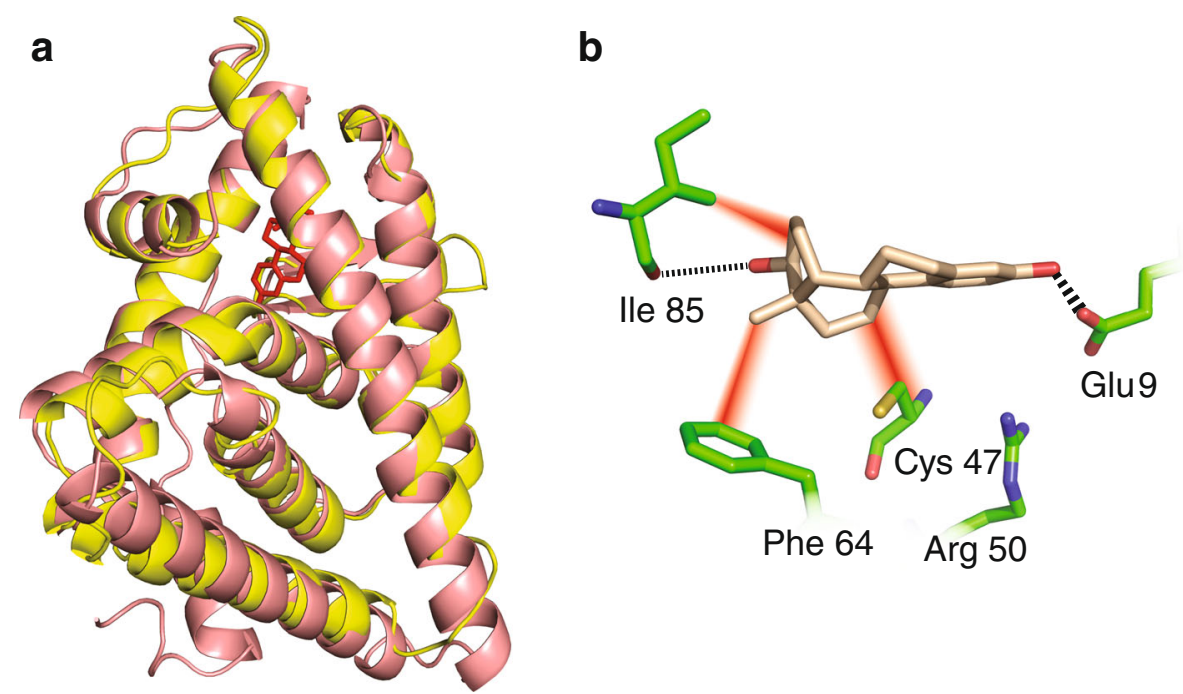

Fig. $1 \mathrm{~A}$ homology model of the 3D structure of the B. manjavacas estrogen-like receptor LBD (yellow). a Superimposition of the rotifer (model) and human (X-ray) ER LBDs (pink). The model suggests that the structure of the binding pocket is conserved between human and rotifer. $\mathbf{b}$ Close up view of the rotifer ER LBD ligand binding site occupied by estradiol. The amino acids that form the ligand binding site are indicated. Hydrogen bonds are dashed black lines. van der Waals contacts are diffuse red lines. The 3D structure of the human ER LBD was used as a template to construct the 3D model of the rotifer estrogen-like receptor LBD

Figure S2) demonstrate localized binding in specific tissues, including ovaries and vitellarium (yolk gland) (Fig. 2). Auto-fluorescence and other confounding signals were not observed in rotifers treated with estradiol alone.

\section{Genetic selection using the rotifer estrogen-like receptor}

Yeast two hybrid assays [37-40] were used to assay estradiol and AMI probe binding to the putative ER of rotifer. Yeast growth is observed when two fusion proteins associate in a ligand dependent fashion (Fig. 3). Minimal growth is seen in the negative control, with no ligand added to the media. AMI probes tested here were limited to those that gave positive results binding to the human ER in chemical complementation studies. Ligandactivated growth was observed for the rotifer estrogenlike receptor with all ligands tested here (Fig. 3). Cells grown in AB-18 grew 40\% more than the samples with estradiol.

\section{Chromophore range finding assays}

AMI probes and estradiol (Additional file 2: Figure S2) were tested for rotifer toxicity. Inhibitory effects on B. manjavacas reproduction after $72 \mathrm{~h}$ were observed in estradiol concentrations of $20 \mu \mathrm{M}(\mathrm{t}=3.16, \mathrm{df}=6$, $P=0.020), \quad 40 \mu \mathrm{M} \quad(\mathrm{t}=12.73, \mathrm{df}=6, P=0.000)$, and $60 \mu \mathrm{M}(\mathrm{t}=8.49, \mathrm{df}=6, P=0.000)$. AB-89 had inhibitory effects on $B$. manjavacas reproduction at $40 \mu \mathrm{M}$ $(\mathrm{t}=5.00, \mathrm{df}=6, P=0.020)$. B. manjavacas exposure to any AMI probe at $10 \mu \mathrm{M}$ had no significant effect on rotifer reproduction. Therefore, we exposed rotifers to $10 \mu \mathrm{M}$ of the AMI probes for the remainder of the study.

\section{Rotifer survival}

No significant lifespan extension or reduction was observed in $B$. manjavacas neonates treated with $10 \mu \mathrm{M}$ AMI probes or estradiol, relative to untreated control (Fig. 4a). Only rotifers treated with AB-9 had a significantly lower survival rate. The following $P$ values are from log-rank tests: Estradiol $(P=0.679), \mathrm{AB}-18 \quad(P=0.092)$, AB-9 $(P=0.003,25 \%$ lower survival $)$, AB-89 $(P=0.961)$, AB-43 $(P=0.843)$ and AB-1 $(P=0.371)$.

\section{Reproduction tests}

B. manjavacas reproduction began after 2 days and mean offspring production per female peaked on days 4 or 5 for all AMI probe treatments. Reproduction ceased after 14 days. Exposure to AB-89 at $10 \mu \mathrm{M}$ significantly increased lifetime reproduction of rotifer females by $38 \%$. The average reproductive rate for $B$. manjavacas reproduction increased from 18 to 24 offspring per animal $(\mathrm{t}=-2.57, \mathrm{df}=39, P=0.007)$. Estradiol at $10 \mu \mathrm{M}$ showed no significant effect on reproductive output of $B$. manjavacas. In contrast, AB-89 significantly increased reproduction by $26 \%, 19-24$ offspring per animal $(\mathrm{t}=-2.16, \mathrm{df}=43, P=0.018)$ (Fig. $4 \mathrm{~b})$.

\section{Modeling of putative ER LBD from rotifer}

A sequence alignment of the rotifer ER-like LBD with known ER LBD sequences reveals that the amino acid 


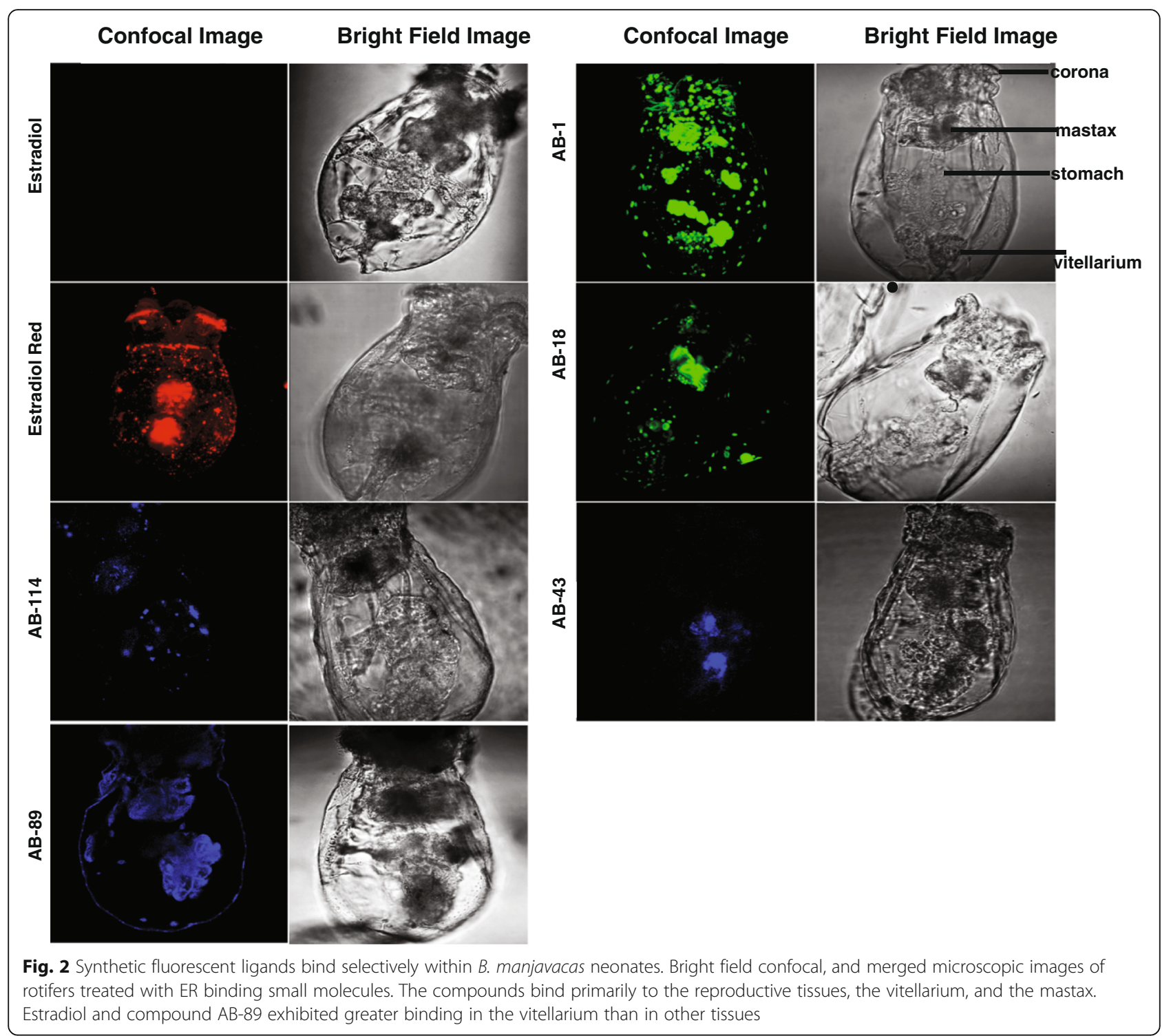

sequence of the rotifer ER-like LBD is highly conserved relative to known ER LBDs (Table 1). The sequence of the ligand-binding pocket of rotifers falls within the consensus of other ER LBD ligand binding pockets (Additional file 1: Figure S1). The rotifer putative ER LBD is $68 \%$ conserved when compared to the human ER LBD (Table 1 and Additional file 1: Figure S1).

Homology modeling of the rotifer ER-like LBD, using the human ER LBD as a template, provides a reasonable model (Fig. 1). The homology model returns the anticipated global fold, with correct disposition of the amino acids known to be involved in ligand binding. We have well-grounded estimates of the accuracy of the rotifer ER-like LBD model. The accuracy of the model indicates it is useful for understanding the structure of the binding pocket and the selectivity of ligand binding. It is clear that the rotifer ER-like LDB does not have an obstructed binding pocket. We estimate that RMS error in atomic positions of the rotifer model vs. the actual structure (unknown) to be approximately 1.69 (Fig. 5). This value is an upper bound of the errors in the binding site in our system because canonical secondary structures such as the $\alpha$-helices that form the ligand binding site are the most accurately predicted part of the model.

\section{Discussion}

This work demonstrates the effect on reproduction of ligand binding to the rotifer estrogen-like receptor and suggests an ancient role for the ER in regulating animal reproduction. We identify and characterize an estrogenlike receptor in the phylum Rotifera. Our principal 


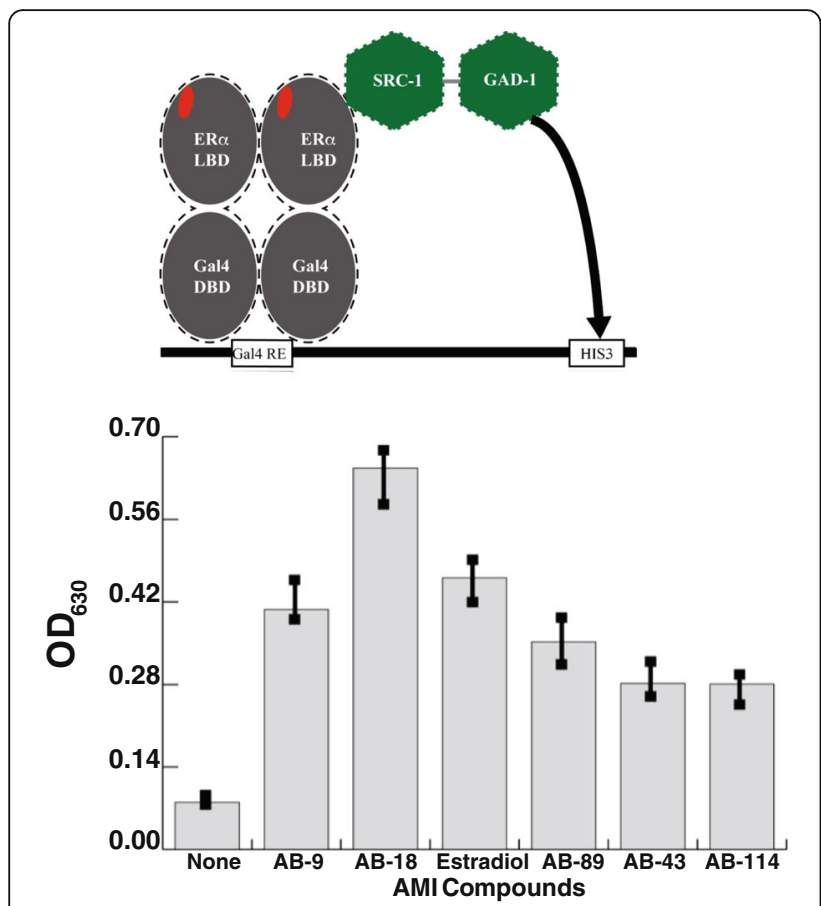

Fig. 3 Chemical Complementation is a binding assay. This assay couples yeast survival to the presence of a small molecule ligand (red). The yeast contains the GAL4 response element that controls the expression of HIS3 biosynthesis genes. The rotifer putative ER LBD is fused to a GAL4 DNA binding domain (GBD). This fusion protein binds to the GAL4 response element. Ligand binding by the ER LBD leads to recruitment of the SRC-1 coactivator, which is fused to the GAL4 activation domain (GAD). Transcription of the histidine biosynthesis genes, upon ligand binding, allows the yeast to survive in media lacking histidine [37-40]. The results show that estradiol and the synthetic fluorescent ligands bind to the rotifer the ER-like LBD in vivo. The negative control (with no added ligand) exhibited minimal growth. The natural ligand, estradiol, increases growth on the same order as the synthetic ligands. Neither estradiol, nor the synthetic fluorescent compounds have any effect on yeast growth in the absence of Gal4-ER [35]

hypothesis is that this putative ER is functional in the rotifer, $B$. manjavacas, where it interacts with small ligands and controls reproduction.

These studies identify a putative rotifer ER and provide evidence ER chemoreception as a regulatory step in rotifer reproduction. We first identified an estrogen-like receptor gene sequence in the transcriptome of $B$. manjavacas. The identification of a putative ER-like receptor in the rotifer transcriptome is especially significant because active transcription signifies the need for estrogen signaling during rotifer development. Sequence alignments of the rotifer putative ER against the sequences of other animals illustrate a significant degree of similarity between the rotifer putative ER and those from higher animals. We performed three-dimensional homology modeling of the rotifer ER-like LBD, using the experimental structure of the human ER LBD as a template.
This model allowed us to characterize the ligand binding pocket in the rotifer ER (Fig. 1). Future work includes isolating the DNA Binding domain of the ER-like receptor.

Using fluorescent probes that bind specifically to the rotifer ER-like LBD (Fig. 3) [35] we demonstrate localization of the ER within the reproductive tissues of female rotifers (Fig. 2). The probe localization varies slightly between the different probe types, however, this could be due to varying binding affinity to the probes, a phenomenon also seen in mammalian cells [41]. However, all probes exhibit significant binding within the reproductive tissues of the rotifer. This localization is consistent with observations of ER localization in other animals. Future work will include completing in situ hybridizations to determine the localization of the expressed mRNA as well. A comparison of the protein vs RNA localization could prove helpful.

Next, we tested the probes for specific binding to the ER in yeast genetic selection assays because probe binding to rotifer reproductive tissues does not alone demonstrate probe specificity. We verified the functional binding of the AMI probes, as well as estradiol, to the rotifer putative ER in the yeast genetic selection assays. Our results indicate that estradiol and the AMI probes in fact bind to the rotifer ER-like LBD.

These data are consistent with specific binding of both estradiol and the AMI probes to human ER. The activation seen upon binding to the rotifer ER-like LBD is significant because, although an ER -like receptor has been identified in mollusks, it is constitutively activated, independent of small molecule ligands [42]. In contrast to the occluded mollusk ER ligand-binding site [42], our homology models suggest the rotifer ER binding site is not occluded. This is consistent with our observation of ligand activation.

Although other studies have questioned the synthesis of steroid hormones in lophotrochozoans [43], our results complement previous work in rotifers and steroid signaling. Specifically, our work parallels the identification of progesterone and a progesterone receptor in rotifers [13]. While the focus of our study was not to identify the natural ligand for the ER-like receptor, vertebrate steroids have long been recognized to have in vivo biological effects in rotifers that may include regulation of sexual and asexual reproduction [21, 25-29]. Furthermore, the identification of key enzymes required for sex steroid biosynthesis in rotifers further supports our data [24]. Further biological characterization of both the rotifer ER-like receptor and the identified enzymes is required to provide more insight into the function of the receptor in rotifers.

Though the rotifer homology model provides considerable support of the presence of a physiological ligand 

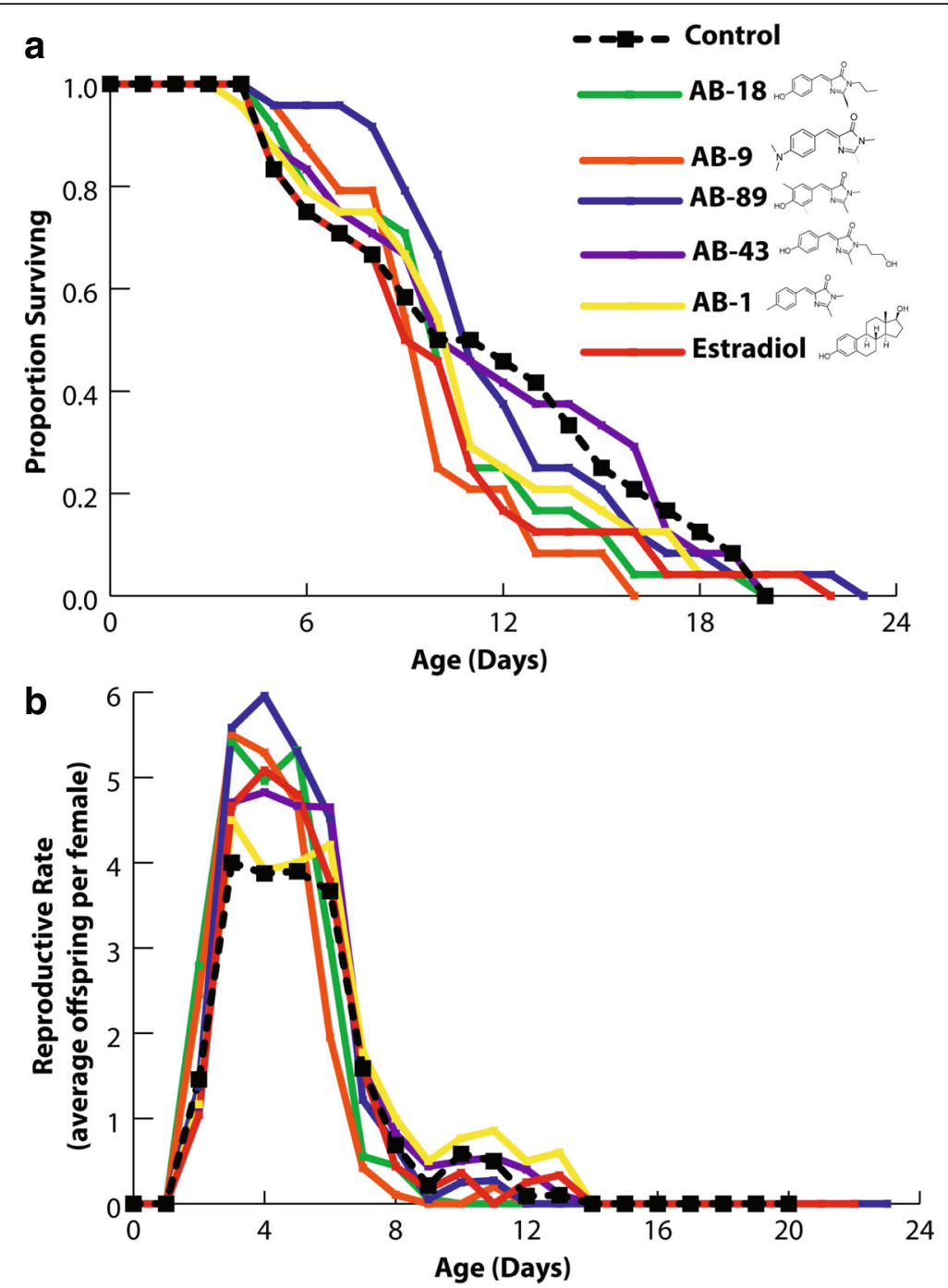

Fig. 4 a Survivorship of rotifers treated with estrogen-like receptor binding small molecules. b manjavacas neonates were treated with $10 \mu \mathrm{M}$ of each compound for the duration of their life. No significant changes in lifespan were observed in the treated animals when compared to animals grown without ligands. $\mathbf{b}$ AMI ligands do not negatively affect the reproductive rate of rotifers. The effects of ER binding AMI molecules on rotifer reproduction are shown above. AB-89 significantly increased reproduction compared to the control group. Exposure to ER binding AMI molecule AB-89 at $10 \mu \mathrm{M}$ significantly increased by $38 \%$. The average reproductive rate for B. manjavacas reproduction increased from 18 to 24 offspring per female

for the rotifer estrogen-like receptor, it is likely that the ligand is unlike human estradiol. Previous studies provide evidence that steroid signaling was independently recruited many times from slightly different molecules [43]. Testing of this hypothesis will come from the isolation of a natural ligand for the rotifer estrogen-like receptor.

Physiological assays with rotifers with both the AMI probes and estradiol confirm that the probes and estradiol function similarly. Neither estradiol nor the probes cause an increase in mortality at $10 \mu \mathrm{M}$ (Fig. 4a). Treatment with the probe AMI-89 resulted in a significant increase in reproductive output of female rotifers (Fig. 4b). This work can be completed with the natural ligand, once isolated to conclude more definitively the function of the ER-like receptor in rotifers. While this work is far from definitive, it does provide significantly more evidence of the evolution of the estrogen receptor.

Collectively, our results suggest that an estrogen-like compound plays a central role in regulating reproduction of the ancestral microinvertebrate B. manjavacas (Rotifera). The ER exhibits conservation of structure and function over a broad expanse of animal phylogeny. The presence and activity of a putative ER in the Phylum Rotifera confirms the ancient ancestry of the ER. 


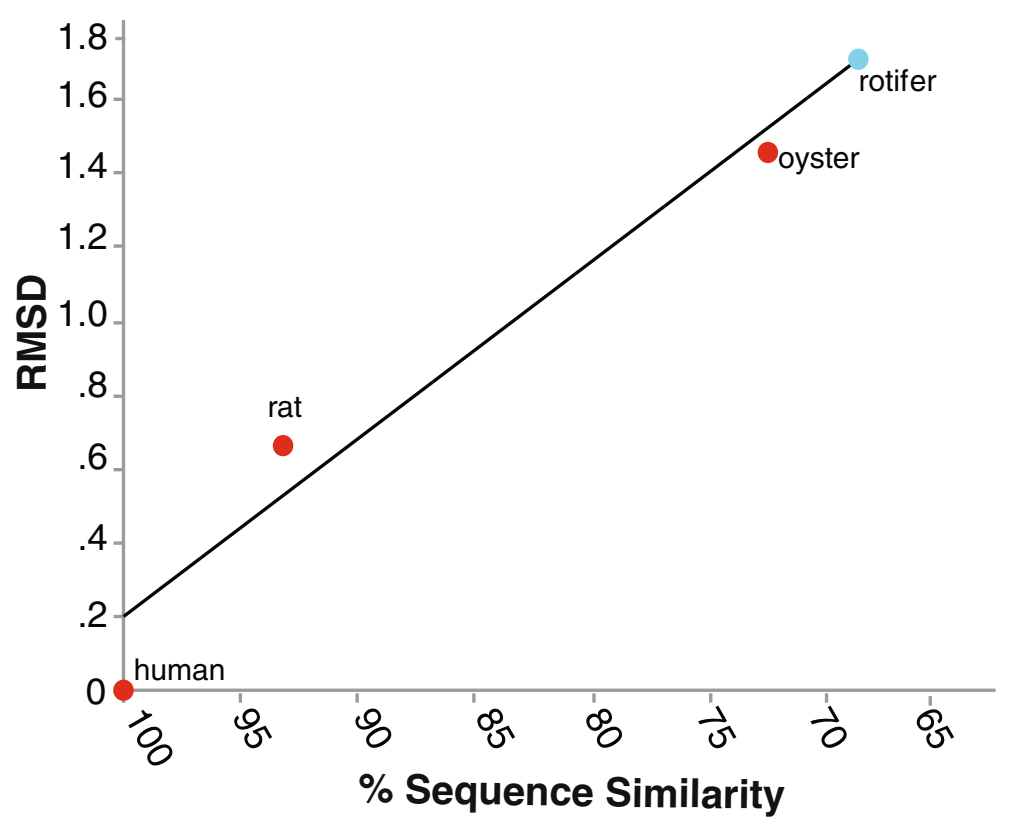

Fig. 5 Error estimate for the rotifer ER-like LBD homology model. RMSD of atomic positions ( $\AA$ ) were calculated by superimposing the homology model for each organism against the real crystal structure. RMSD values vs. percentage sequence similarity are plotted. We can estimate the RMSD of the rotifer ER-like LBD model based on its sequence similarity to the human ER LBD. The estimated RMS error for the rotifer model is $1.7 \AA$. $R^{2}=0.95$

\section{Conclusions}

Here we have identified and characterized an ER-like receptor in the Phylum Rotifera. Our study provides an initial synthesis of computational, chemical and biological techniques to confirm the structure and function of this receptor in B. manjavacas, an ancestral invertebrate. Chemical cues have long been hypothesized to mediators for the switch from asexual to sexual reproduction in rotifer populations. This study provides evidence that microscopic invertebrates' reproductive development may also be controlled by ligand activated signaling.

\section{Methods}

\section{Rotifer culturing}

B. manjavacas $[44,45]$ neonates were hatched from resting eggs in $15 \mathrm{ppt}$ artificial seawater (ASW, Instant Ocean salts) under constant fluorescent illumination at $25{ }^{\circ} \mathrm{C}$. B. manjavacas was originally collected from Azov Sea and was previously known as Brachionus plicatilis $[16,46]$. B. manjavacas has been cultured continuously in the Snell laboratory since 1983 [13].

\section{ER identification and homology modeling}

Querying the B. manjavacas transcriptome database (https://www.ncbi.nlm.nih.gov/genbank/) using the human ER and the BLASTX tool [47] returned a rotifer ER cDNA sequence. Alignments using its deduced amino acid sequences were conducted with CLUSTALW [48].
The ER ligand binding domain (LDB) was modeled with the SWISS-MODEL tool of the Swiss PDB Viewer [49] using human ER structure (PDB 1ERE) as a template. The efficacy of the SWISS-MODEL tool for modeling ER structures was verified by modeling additional ER LBDs. We constructed models of a series of ER LBDS and compared the homology models with corresponding $\mathrm{x}$-ray structures, which are known. Modeled ER LBDs from animals (oyster, rat, human and rotifer), using human as the template, were superimposed on the corresponding crystal structures. Root mean square deviations (RMSDs) of atomic positions were calculated to determine relationships of sequence similarity (human template compared to model) and degree of error in the model in three dimensions (model compared to $\mathrm{x}$-ray structure). The RMSDs were plotted against the amino acid similarity. A trend line was used to predict the RMSD for the rotifer model versus the real (unknown) rotifer structure. In short we made an ER-specific error model, following a previous more general method [50] for assaying the quality of homology models.

\section{In silico binding of AMI fluorophore ligand to the Rotifer ER}

Structures of AMI fluorophore probes were energy minimized with ChemBioDraw 3D Ultra (Cambridge Soft, USA). In silico docking of the probes to the rotifer ER LBD was carried out with Autodock Vina [51]. The ER was prepared for docking via UCSF CHIMERA, an 
interactive molecular graphics program, by removing the ligand and water molecules, adding polar hydrogens, and assigning Kollman united atom charges. The lowest energy ligand/receptor complexes were subjected to further studies. Final images with docking results were rendered in PyMOL.

\section{Interaction quantification assay in yeast}

All known proteins that fluoresce in the visible region contain the AMI moiety [52]. Green fluorescent protein (GFP) for example contains a hydroxybenzylidene AMI probe within a ß-barrel. Natural AMIs are autosynthesized within the folded protein from aromatic amino acids. Recently, we have adapted the use of AMIs to turn on fluorescence from a variety of biological binding molecules, including proteins [53]. The structural similarity of estradiol and appropriately substituted AMIs suggested that these fluorophores would provide excellent candidates for turn-on fluorescence in the presence of ER receptors. We adapted the Bazureau synthesis to generate an extensive library of AMI fluorophores, outside the context of a protein [54].

\section{Expression and purification of the rotifer ER LBD}

The DNA sequence encoding the putative ER LBD from rotifer was synthesized by recursive PCR [55] and cloned into the pGADT7 AD expression vector. The rotifer ER LBD in pGADT7 was transformed into the yeast strain PJ694A using the lithium acetate transformation procedure [56]. Transformants were selected in media lacking leucine and tryptophan.

\section{Genetic selection using the rotifer putative ER}

A yeast genetic selection assay [57] was performed to assay binding of florophores and estradiol to the rotifer putative ER LBD. The yeast two-hybrid assay was performed in the PJ69-4A strain and has been previously described [57-59]. Interaction of AMI probes with the rotifer ER receptor results in the activation of the GAL4 promoter and the production of histidine (Fig. 3). Interactions were assayed in 96-well plates with media lacking histidine, leucine, and tryptophan (SC- HLW). The media contained $0.1 \mathrm{mM}$ 3-amino-1, 2,4-triazole (3-AT) and were tested with and without AMI fluorophore ligands or $17 \beta$-estradiol at varying concentrations (ranging from $10 \mathrm{nM}$ to $10 \mu \mathrm{M}$ ). As a control, untransformed yeast were also tested for selection with the AMI compounds and EST. Yeast cells were added to 96-well plates to a final concentration of $3.0 \times 10^{6}$ cells $/ \mathrm{ml}$. Plates were incubated at $30{ }^{\circ} \mathrm{C}$, with shaking at $170 \mathrm{rpm}$. Optical density (OD) readings at $630 \mathrm{~nm}$ were recorded at 0,24 , and $48 \mathrm{~h}$. The affinity of each AMI fluorophore ligand for the rotifer ER receptor was estimated quantitatively by growth of the yeast.

\section{Concentration range finding in rotifers}

Waterborne exposures to AMI compounds and estradiol were used in these experiments because they were the most feasible. With this method of exposure, the actual dose to the rotifer is most likely significantly lower due to uncertainties in ingestion, absorption, assimilation, and excretion [24]. Each AMI probe was diluted with 15 ppt ASW to $10,20,40$, and $60 \mu \mathrm{M}$ to give a final volume of $5 \mathrm{~mL}$ for each. ASW alone and 20:80 DMSO/ Ethanol diluted with ASW were used negative controls. Each treatment was assigned to and dispensed in $1 \mathrm{~mL}$ quantities to 4 wells in a 24 -well plate. A B. manjavacas hatchling $4-6 \mathrm{~h}$ old was added to each well. After a 30 min incubation, $200 \mu \mathrm{L}$ of the algae Tetraselmis suecica diluted with 15 ppt ASW was added, for a final algae concentration of about to $2 \mathrm{e}^{5}$ cells per ml. Plates were kept at $25{ }^{\circ} \mathrm{C}$ in low light. At $24 \mathrm{~h}$ intervals over the next $72 \mathrm{~h}$, the offspring produced in each well were recorded and removed. The highest concentration of AMI probe in which there was no inhibition of rotifer reproduction was observed to be $10 \mu \mathrm{M}$ for all ligands tested. A concentration of $10 \mu \mathrm{M}$ was used for survivorship and fecundity analysis, as well as, in confocal microscopy experiments.

\section{Confocal fluorescence microscopy}

Approximately 15 - $30 \mathrm{~B}$. manjavacas were incubated at room temperature for $1 \mathrm{~h}$ in AMI probe at $10 \mu \mathrm{M}$ in $100 \mu \mathrm{L}$ of $15 \mathrm{ppt}$ ASW. Negative controls were incubated 20:80 DMSO/Ethanol. The animals were anesthetized with $200 \mu \mathrm{L}$ carbonated water, fixed with $5 \mu \mathrm{L} 20 \%$ formalin, pelleted, and placed in $250 \mu \mathrm{L}$ of PBS (130 mM NaCl, $10 \mathrm{mM} \mathrm{NaH} \mathrm{PO}_{4}, \mathrm{pH}$ 7.2). Samples were stored at $4{ }^{\circ} \mathrm{C}$ in the dark until they were imaged. Imaging was performed using a Zeiss LSM 700-405 confocal microscope, with magnification of 63X Oil DIC with excitation at $405 \mathrm{~nm}$.

\section{Lifespan and reproduction tests}

A 24-well plate was set up for each treatment, with one $B$. manjavacas hatchling per well containing $1 \mathrm{~mL}$ of $T$. suecica $\left(2 \times 10^{5}\right.$ cells $\left./ \mathrm{mL}\right)$. Prior to the addition of the hatchlings, each AMI probe was diluted to $10 \mu \mathrm{M}$ with the $T$. suecica and 15 ppt ASW mixture. Once again, with waterborne exposures to AMI compounds and estradiol, the actual dose to the rotifer is most likely significantly lower due to uncertainties in ingestion, absorption, assimilation, and excretion [24]. However, this study does reveal the sensitivity of rotifers to estradiol as well as the ER binding AMI compounds. A negative control plate with only a 20:80 DMSO/Ethanol solution $(10 \mu \mathrm{M})$ was prepared. Plates were stored at $22{ }^{\circ} \mathrm{C}$ in low light. Every $24 \mathrm{~h}$, the frequency of survival was recorded until the death of all 
the test animals. Offspring produced in each well were recorded and removed. After 8 days, animals were transferred to new plates with fresh T. suecica and treatment solutions. A Kaplan-Meier survival analysis was completed to identify the differences in survival between treatments and control. A one-way ANOVA and Dunnett's test was also used to identify differences in reproduction and survival between treatments and control.

\section{Additional files}

Additional file 1: Figure S1. The alignment of the ER LBD amino acid sequences of rotifer and human shows significant similarity. Conserved amino acids are green. Similar amino acids are cyan. Amino acids that directly interact with the estradiol ligand are boxed (rotifer, red; human; blue). These amino acids are highly conserved as well. (XLS 258 kb)

Additional file 2: Figure S2. Six fluorescent synthetic ligands (AMIs) were tested for in vivo binding to ER in live rotifer neonates and with the yeast chemical complementation assay using a cloned rotifer ER LBD. These compounds were chosen because previous work verified their binding to the human ER LBD in yeast chemical complementation assays. These compounds fluoresce upon binding to their target [35]. Estradiol is the natural ligand for the human ER and does not fluoresce. (XLS $47 \mathrm{~kb}$ )

\section{Abbreviations}

AMI: Fluorescent arylideneimidazolidinone; ER: Estrogen receptor; ERB: Estrogen receptor binding protein; EST: Estradiol 17-B dehydrogenase; LBD: Ligand binding domain; MIP: Mixis Inducing Protein; P450: Cytochrome P450 4VC; RMSDs: Root mean square deviations; SOA: Sterol O-acyltransferase 1; SPH: 12 sphingolipid delta 4 desaturase/C-4 hydroxylase; SR: Steroid reductase

\section{Acknowledgements}

We would like to thank the three anonymous reviewers and the editor Dr. Becks for very helpful suggestions on our paper. We thank David Mark Welch for providing access to the rotifer transcriptomes database (https:// www.ncbi.nlm.nih.gov/genbank/). We also thank Lelani Barry and Samantha Dean for their technical assistance.

\section{Funding}

This work was supported by the National Institute of Aging; grant R01 AG037960-02 and National Aeronautics and Space Administration Astrobiology Institute (NNA09DA78A).

\section{Availability of data and materials}

All data supporting our findings is contained within the manuscript.

\section{Authors' contributions}

$B \sqcup$ carried out rotifer culturing, genetic selection assays, homology modeling, completed the lifespan and reproductive assays and drafted the manuscript. CLW synthesized the fluorescent synthetic ligands and completed the docking simulations. BA, LT, LDW and TWS participated in the design and coordination of the study, and helped to draft the manuscript. All authors read and approved the final manuscript.

\section{Competing interests}

The authors declare that they have no competing interests.

\section{Consent for publication}

Not applicable.

Ethics approval and consent to participate Not applicable.

\section{Author details}

'School of Biology, Georgia Institute of Technology, Atlanta, GA 30332-0230, USA. ${ }^{2}$ School of Chemistry and Biochemistry, Georgia Institute of Technology, Atlanta, GA 30332-0230, USA. ㄹDasman Diabetes Institute, P.O. Box 1180, Dasman 15462, Kuwait.

Received: 12 February 2016 Accepted: 8 February 2017

Published online: 04 March 2017

\section{References}

1. Baker ME. Steroid receptor phylogeny and vertebrate origins. Mol Cell Endocrinol. 1997;135(2):101-7.

2. Baker ME. Adrenal and sex steroid receptor evolution: environmental implications. J Mol Endocrinol. 2001;26(2):119-25.

3. Escriva H, Safi R, Hanni C, Langlois MC, Saumitou-Laprade P, Stehelin D, Capron A, Pierce R, Laudet V. Ligand binding was acquired during evolution of nuclear receptors. Proc Natl Acad Sci U S A. 1997;94(13):6803-8.

4. Thornton JW. Evolution of vertebrate steroid receptors from an ancestra estrogen receptor by ligand exploitation and serial genome expansions. Proc Natl Acad Sci U S A. 2001:98(10):5671-6.

5. Baker ME. Evolution of adrenal and sex steroid action in vertebrates: a ligand-based mechanism for complexity. Bioessays. 2003;25(4):396-400.

6. Thornton JW, Need E, Crews D. Resurrecting the ancestral steroid receptor: ancient origin of estrogen signaling. Science. 2003;301(5640): 1714-7.

7. Keay J, Thornton JW. Hormone-activated estrogen receptors in annelid invertebrates: implications for evolution and endocrine disruption. Endocrinology. 2009;150(4):1731-8.

8. DeFur PL. Endocrine Disruption in Invertebrates: Endocrinology, Testing, and Assessment. Pensacola, Fla: SETAC Press, 1999. Print.

9. Benotti MJ, Trenholm RA, Vanderford BJ, Holady JC, Stanford BD, Snyder SA. Pharmaceuticals and endocrine disrupting compounds in U.S. Drinking water. Environ Sci Technol. 2009:43(3):597-603.

10. Kohler HR, Kloas W, Schirling M, Lutz I, Reye AL, Langen JS, Triebskorn R, Nagel R, Schonfelder G. Sex steroid receptor evolution and signalling in aquatic invertebrates. Ecotoxicology. 2007;16(1):131-43.

11. Di Cosmo A, Di Cristo C, Paolucci M. A estradiol-17beta receptor in the reproductive system of the female of octopus vulgaris: characterization and immunolocalization. Mol Reprod Dev. 2002:61(3):367-75.

12. Lafont $R$, Mathieu M. Steroids in aquatic invertebrates. Ecotoxicology. 2007;16(1):109-30

13. Stout EP, La Clair JJ, Snell TW, Shearer TL, Kubanek J. Conservation of progesterone hormone function in invertebrate reproduction. Proc Natl Acad Sci U S A. 2010;107(26):11859-64.

14. Wallace RL, Snell TW, Ricci C, Nogrady T. Part 1: biology, ecology and systematics. Guides to the identification of microinvertebrates of the continental waters of the world. Ghent: Backhuys Publishers; 2006.

15. Kubanek J, Snell TW. Quorum Sensing in Rotifers. Chem Commun Bact. Washington DC: ASM Press; 2008. p. 453-61.

16. Snell TW, Kubanek J, Carter W, Payne AB, Kim J, Hicks MK, Stelzer C. A protein signal triggers sexual reproduction in Brachionus plicatilis (Rotifera). Mar Biol. 2006;149:763-73.

17. Ollevier F, Declerck D, Diederik H, Deloof A. Identification of nonecdysteroid steroids in hemolymph of both male and female astacus-leptodactylus (crustacea) by Gas-chromatography mass-spectrometry. Gen Comp Endocrinol. 1986;61(2):214-28.

18. Mizuta T, Kubokawa K. Presence of sex steroids and cytochrome P450 genes in amphioxus. Endocrinology. 2007;148(8):3554-65.

19. Edgecombe GD, Giribet G, Dunn CW, Hejnol A, Kristensen RM, Neves RC, Rouse GW, Worsaae K, Sorensen MV. Higher-level metazoan relationships: recent progress and remaining questions. Org Divers Evol. 2011;11(2):151-72.

20. Smith HA, Welch DBM, Snell TW. Molecular evolution of the membrane associated progesterone receptor in the brachionus plicatilis (rotifera, monogononta) species complex. Hydrobiologia. 2011;662(1):99-106.

21. Snell TW, DesRosiers NJD. Effect of progesterone on sexual reproduction of Brachionus manjavacas (Rotifera). J Exp Mar Biol Ecol. 2008:363(1-2):104-9.

22. Denekamp NY, Thorne MA, Clark MS, Kube M, Reinhardt R, Lubzens E. Discovering genes associated with dormancy in the monogonont rotifer Brachionus plicatilis. BMC Genomics. 2009;10:108. 
23. Suga K, Welch DM, Tanaka Y, Sakakura Y, Hagiwara A. Analysis of expressed sequence tags of the cyclically parthenogenetic rotifer Brachionus plicatilis. PLoS One. 2007;2(7):e671.

24. Snell TW. A review of the molecular mechanisms of monogonont rotifer reproduction. Hydrobiologia. 2011;662(1):89-97.

25. Gallardo WG, Hagiwara A, Snell TW. Effect of juvenile hormone and serotonin (5-HT) on mixis induction of the rotifer Brachionus plicatilis Muller. J Exp Mar Biol Ecol. 2000;252(1):97-107.

26. Gallardo WG, Hagiwara A, Tomita Y, Snell TW. Effect of growth hormone and gamma-aminobutyric acid on Brachionus plicatilis (Rotifera) reproduction at low food or high ammonia levels. J Exp Mar Biol Ecol. 1999;240(2):179-91.

27. Gallardo WG, Hagiwara A, Tomita Y, Soyano K, Snell TW. Effect of some vertebrate and invertebrate hormones on the population growth, mictic female production, and body size of the marine rotifer Brachionus plicatilis Muller. Hydrobiologia. 1997;358:113-20.

28. Preston B, Snell T, Dingman B. Use of the freshwater rotifer Brachionus calyciflorus in a screening assay for potential endocrine disruptors. Environ Toxicol Chem. 2000;19:2923-8.

29. Yang JX, Snell TW. Effects of progesterone, testosterone, and estrogen on sexual reproduction of the rotifer brachionus calyciflorus. Int Rev Hydrobiol. 2010;95(6):441-9

30. Snell TW, Joaquim-Justo C. Workshop on rotifers in ecotoxicology. Hydrobiologia. 2007;593:227-32.

31. Walker CL, Lukyanov KA, Yampolsky IV, Mishin AS, Bommarius AS, Duraj-Thatte AM, Azizi B, Tolbert LM, Solntsev KM. Fluorescence imaging using synthetic GFP chromophores. Curr Opin Chem Biol. 2015;(7):64-74.

32. Yague JG, Lavaque E, Carretero J, Azcoitia I, Garcia-Segura LM. Aromatase, the enzyme responsible for estrogen biosynthesis, is expressed by human and rat glioblastomas. Neurosci Lett. 2004;368(3):279-84.

33. Brown KA, Sayasith K, Bouchard N, Lussier JG, Sirois J. Molecular cloning of equine 17 beta-hydroxysteroid dehydrogenase type 1 and its downregulation during follicular luteinization in vivo. J Mol Endocrinol. 2007;38(1-2):67-78

34. Bu HF, Kashireddy P, Chang J, Zhu YT, Zhang ZY, Zheng W, Rao SM, Zhu YJ. ERBP, a novel estrogen receptor binding protein enhancing the activity of estrogen receptor. Biochem Biophys Res Commun. 2004;317(1):54-9.

35. Walker CL, Lukyanov KA, Yampolsky IV, Mishin AS, Bommarius AS, Duraj-Thatte AM, Azizi B, Tolbert LM, Solntsev KM. Fluorescence imaging using synthetic GFP chromophores. Curr Opin Chem Biol. 2015;27:64-74.

36. Sievers F, Higgins DG. Clustal omega, accurate alignment of very large numbers of sequences. Mult Seq Alignment Methods. 2014;1079:105-16.

37. Schwimmer LJ, Rohatgi P, Azizi B, Seley KL, Doyle DF. Creation and discovery of ligand-receptor pairs for transcriptional control with small molecules. Proc Natl Acad Sci U S A. 2004;101(41):14707-12.

38. Azizi B, Chang El, Doyle DF, Schwimmer LJ. Chemical complementation: a high throughput system for nuclear receptor drug discovery. Abstr Pap Am Chem Soc. 2005;229:U186.

39. Azizi B, Doyle DF. Chemical complementation: a genetic selection system in yeast for drug discovery, protein and enzyme engineering. FASEB J. 2006:20(4):A464.

40. Doyle DF, Schwimmer LJ, Azizi B, Rohatgi P. Chemical complementation: protein engineering through genetic selection. Abstr Pap Am Chem Soc. 2005;229:U213.

41. Duraj-Thatte A. Fluorescent GFP chromophores as potential ligands for various nuclear receptors. PhD diss., Georgia Institute of Technology, 2012.

42. Bridgham JT, Keay J, Ortlund EA, Thornton JW. Vestigialization of an allosteric switch: genetic and structural mechanisms for the evolution of constitutive activity in a steroid hormone receptor. Plos Genet. 2014;10(1):e1004058.

43. Markov GV, Tavares R, Dauphin-Villemant C, Demeneix BA, Baker ME, Laudet $V$. Independent elaboration of steroid hormone signaling pathways in metazoans. Proc Natl Acad Sci. 2009;106(29):11913-8.

44. Fontaneto D, Herniou EA, Boschetti C, Caprioli M, Melone G, Ricci C, Barraclough TG. Independently evolving species in asexual bdelloid rotifers. PLoS Biol. 2007;5(4):e87.

45. Fontaneto D, Giordani I, Melone G, Serra M. Disentangling the morphological stasis in two rotifer species of the Brachionus plicatilis species complex. Hydrobiologia. 2007:583:297-307.
46. Rico-Martínez R, Snell TW. Comparative binding of antibody to a mate recognition pheromone on female Brachionus plicatilis and Brachionus rotundiformis (Rotifera). Hydrobiologia. 1997;358(1):71-6.

47. Altschul SF, Gish W, Myers EW, Lipman DJ. Basic local alignment search tool. J Mol Biol. 1990;215:403-10.

48. Thompson JD, Higgins DG, Gibson TJ. Clustal W: improving sensiticity of progressive multiple sequence alignment through sequence weighting, position-specific gap penalties and weight matrix choice. Nucleic Acids Res. 1994:22:4673-80.

49. Guex N, Peitsch MC. SWISS-MODEL and the Swiss-PdbViewer: an environment for comparative protein modeling. Electrophoresis. 1997;18(15):2714-23.

50. Marti-Renom MA, Stuart AC, Fiser A, Sanchez R, Melo F, Sali A. Comparative protein structure modeling of genes and genomes. Annu Rev Biophys Biomol Struct. 2000:29:291-325.

51. Trott O, Olson AJ. Software news and update AutoDock Vina: improving the speed and accuracy of docking with a New scoring function, efficient optimization, and multithreading. J Comput Chem. 2010;31(2):455-61.

52. Tolbert LM, Baldridge A, Kowalik J, Solntsev KM. Collapse and recovery of green fluorescent protein chromophore emission through topological effects. Acc Chem Res. 2012;45(2):171-81.

53. Lee JS, Badridge A, Peng SH, Yang SQ, Kim YK, Tolbert LM, Chang YT. Fluorescence response profiling for small molecule sensors utilizing the green fluorescent protein chromophore and its derivatives. ACS Comb Sci. 2011;13(1):32-8.

54. Lerestif JM, Perrocheau J, Tonnard F, Bazureau JP, Hamelin J. 1,3-dipolar cycloaddition of imidate ylides on imino-alcohols: synthesis of new imidazolones using solvent free conditions. Tetrahedron. 1995;51(24):6757-74.

55. Bowman JC, Azizi B, Lenz TK, Roy P, Williams LD. Preparation of long templates for RNA in vitro transcription by recursive PCR. Methods Mol Biol. 2012;941:19-41.

56. Gietz RD, Woods RA. Transformation of yeast by lithium acetate/singlestranded carrier DNA/polyethylene glycol method. Methods Enzymol. 2002;350:87-96.

57. Azizi B, Chang El, Doyle DF. Chemical complementation: small-molecule-based genetic selection in yeast. Biochem Biophys Res Commun. 2003;306(3): 774-80.

58. Schwimmer $\sqcup$, Rohatgi P, Azizi B, Seley KL, Doyle DF. Creation and discovery of ligand-receptor pairs for transcriptional control with small molecules. Proc Natl Acad Sci U S A. 2004;101(41):14707-12.

59. Shaffer HA, Rood MK, Kashlan B, Chang El, Doyle DF, Azizi B. BAPJ69-4A: a yeast two-hybrid strain for both positive and negative genetic selection. J Microbiol Methods. 2012;91(1):22-9.

\section{Submit your next manuscript to BioMed Central and we will help you at every step:}

- We accept pre-submission inquiries

- Our selector tool helps you to find the most relevant journal

- We provide round the clock customer support

- Convenient online submission

- Thorough peer review

- Inclusion in PubMed and all major indexing services

- Maximum visibility for your research

Submit your manuscript at www.biomedcentral.com/submit 